\title{
Home state obligations over multinational corporations in human rights treaties
}

Citation for published version (APA):

$\mathrm{Yu}$, L. (2017). Home state obligations over multinational corporations in human rights treaties: with special attention to state-owned corporations. [Doctoral Thesis, Maastricht University]. Maastricht University. https://doi.org/10.26481/dis.20170915ly

Document status and date:

Published: 01/01/2017

DOI:

10.26481/dis.20170915ly

Document Version:

Publisher's PDF, also known as Version of record

\section{Please check the document version of this publication:}

- A submitted manuscript is the version of the article upon submission and before peer-review. There can be important differences between the submitted version and the official published version of record.

People interested in the research are advised to contact the author for the final version of the publication, or visit the DOI to the publisher's website.

- The final author version and the galley proof are versions of the publication after peer review.

- The final published version features the final layout of the paper including the volume, issue and page numbers.

Link to publication

\footnotetext{
General rights rights.

- You may freely distribute the URL identifying the publication in the public portal. please follow below link for the End User Agreement:

www.umlib.nl/taverne-license

Take down policy

If you believe that this document breaches copyright please contact us at:

repository@maastrichtuniversity.nl

providing details and we will investigate your claim.
}

Copyright and moral rights for the publications made accessible in the public portal are retained by the authors and/or other copyright owners and it is a condition of accessing publications that users recognise and abide by the legal requirements associated with these

- Users may download and print one copy of any publication from the public portal for the purpose of private study or research.

- You may not further distribute the material or use it for any profit-making activity or commercial gain

If the publication is distributed under the terms of Article $25 \mathrm{fa}$ of the Dutch Copyright Act, indicated by the "Taverne" license above, 


\section{Summary}

The global operation of MNCs could have negative effects on human rights in a host State. What can we expect from a home State with regard to this phenomenon? What obligations does a home State have under human rights treaties? The problem caused by private abusers could be addressed either by attributing more to States under secondary rules or by developing positive obligations under primary rules. This book addresses the problem of the human rights damage caused by a Stateowned corporation by developing secondary rules on attribution issues, because a State-owned corporation has a close link to the State as an owner. The problem of the human rights damage caused by an ordinary company is tackled by exploring the scope of positive obligations under human rights treaties (primary rules).

The ILC Articles have provided a legal framework for the attribution issues in general. However, these articles have not settled the attribution issue in relation to State-owned corporations. A special rule for attribution is needed in the discourse about universal human rights treaties. The special rule can be designed as follows: 'The conduct of a State-owned corporation should be directly attributed to the State which has the majority ownership in the corporation.' Once the direct attribution can be proven, the extraterritorial application of human rights treaty does not face any obstacles according to the existing case law.

Home State obligations for ordinary companies concern the scope of positive obligations under human rights treaties. This book adopts a unified approach to address the scope of State obligations with regard to all human rights treaties regardless of whether the treaty contains a jurisdiction clause or not. This book has clarified the function of the expression 'individuals within the jurisdiction of a State' in human rights treaties. If a person falls within the jurisdiction of a State, then this person is entitled to positive obligations from this State. Alternatively, if a perpetrator who abuses or may abuse human rights falls within the jurisdiction of a 
State, then the State should also punish this person or prevent this person from abusing human rights.

In the discourse of business and human rights, an $\mathrm{MNC}$ is headquartered in the territory of a home State and therefore within its jurisdiction. Human rights treaties should be interpreted as requiring States to control activities within their own territory in order to not infringe human rights in other countries. This interpretation has been endorsed by human rights treaty bodies. Therefore, home State obligations are possible when a company (a perpetrator) is within its jurisdiction, even if the individual victim is not considered to be within the jurisdiction of the home State.

This book also explored the possibility that individuals located in a host State are within the jurisdiction of a home State for the purpose of invoking a human right. It has argued that due regard should be given to international investment law in the course of the interpretation of jurisdiction in human rights law in order to mitigate the fragmentation of international law. It is submitted that individuals in a host State can be considered to fall within the jurisdiction of a home State to the extent that the home State has limited the regulatory power of the host State through international investment law practice. This interpretation of jurisdiction is specially applied to the obligation to protect and it does not deal with the obligation to fulfill. This approach to the jurisdiction over an individual victim in a host State could build a bridge between human rights law and investment law. 